\title{
중앙아시아 생태환경 개선을 위한 지원과 협력: 우즈베키스탄 아랄 해 오염, 고갈 실태와 한국의 지원 방안
}

이 지 은 (한국외대 중앙아시아연구소 연구교수)

\section{목 차}

1. 서론

2. 아랄 해의 오염, 고갈 및 주민 보건 실태

3. 역내 기구와 우즈베키스탄 정부의 환경 복구 및 개선 노력

4. 결론: 지속가능한 생태환경 보존과 한국의 향후 협력 방안

\section{1. 서론}

아랄 해는 중앙아시아에 위치하며 한때 세계에서 네 번째로 큰 내해(內海)이자 풍부한 어류자 원으로 유명했지만 현재는 20 세기 인류가 초래한 가장 큰 환경 파괴의 산물이자 '공유지의 비 극(tragedy of the commons) $)^{1}$ '의 대표적 예이다. 아랄 해로 흘러들던 아무다리야와 시르다 리야 강의 물을 소련 시기 카자흐스탄, 우즈베키스탄2), 투르크메니스탄 등 각 공화국 사막지대

1) Garrett Hardin, 'The Tragedy of the Commons', SCIENCE, vol. 162, 1968, pp. 1243-1248. 공유지(영어: Common Pool Resource)의 비극은 '지하자원, 초원, 공기, 호수에 있는 고기와 같이 공동체의 모두가 사용해야 할 자원은 사적이익을 주장하는 시장의 기능에 맡겨 두면 이를 당세대에서 남용하여 자원이 고갈될 위험이 있다' 는 내용을 담고 있다. 아랄 해는 '합리' 적인 개별 행위가 집단적으로는 공유자원의 고갈과 같은 재앙적 결과를 초래하 는 '비합리적' 실천의 비극적 사례다. 따라서 이는 시장실패의 요인이 되며 이러한 자원에 대해서는 국가의 관여가 필요하다. 아니면 이해당사자가 모여 일정한 합의를 통해 이용권을 제한하는 제도를 형성해야 한다는 내용이다.

2) 구 소련권 15 개 국가 중 다섯 번째로 영토가 큰 우즈베키스탄은 동서로 약 $1,425 \mathrm{~km}$, 남북으로는 약 $925 \mathrm{~km}$ 로 총 면적이 남한의 4.5 배인 $447,400 \mathrm{~km}^{2}$ 이다. 국토의 $70 \%$ 는 황무지 및 산지로 이루어져 있고 중앙부는 대부분 사막이 다. 시르다리야, 아무다리야 강은 우즈베키스탄 영토의 북쪽과 남쪽을 가로질러 아랄 해로 흘러들어간다. 
의 관개농업(목화재배)에 사용, 아랄 해로의 유입량을 급속히 줄였고 현재는 원량 수량의 $10 \%$ 정도 남아있는 상황이다. 뿐만 아니라 소비에트 시기 중앙아시아 지역에 집중적으로 육성된 목 화산업에 투입된 각종 살충제와 화학비료 등으로 아랄 해와 두 강의 수질 및 일대 토양은 매우 심각하게 오염되었다. 이로 인해 대부분의 전문가들은 아랄 해가 과거의 건강한 상태로 돌아간 다는 것에 대부분 비관적인 전망을 하고 있다. 공유자원에 대한 자유로운 접근으로 인해 일정 기간 개별 사용자(중앙아시아 국가)들은 계속해서 최대한 이익을 취하였지만, 과도한 개발과 무 분별한 이용은 결국 돌이킬 수 없는 환경 파괴와 생태계 교란으로 이어진 것이다.

아랄 해의 상황은 1989 년이 돼서야 비로소 해당지역과 국제사회의 정치적 이슈로 공론화되 기 시작하였다. 중앙아시아 국가들의 ‘공유자원' 인 아랄 해의 성격과 아랄 해 파괴가 불러온 초 국가적인 환경 이슈들은 개별 국가만의 노력으로는 해결되기 어려운 측면이 있기 때문이다. 이 에 1993년 중앙아시아 5 개국 정상은 아랄 해의 실태와 복구 방법 등에 대한 최초의 합의를 도출 하기 위해 첫 모임을 가졌다. ${ }^{3)}$ 이때부터 중앙아시아 국가들과 국제단체가 참여한 다양한 기구 가 창설되었는데, 대표적인 것인 '아랄 해 국가 간 협의회(Interstate Council for the Aral Sea, ICAS)', '아랄 해 살리기 국제펀드(International Fund for the Aral Sea Saving, IFAS)' 와 '중앙아시아 수자원 관리 국가 간 위원회(Interstate Commission for Water Coordination of Central Asia Central, ICWC)' 등이다. 이러한 기구들이 활동을 시작하면 서 아랄 해의 오염과 고갈이 해당 국가들만의 문제라는 시각에서 벗어나 전지구적 차원의 해결 방안을 모색하게 되었다. ${ }^{4)}$ 이와 함께 아랄 해 문제를 중앙아시아와 지구촌 공동의 문제로 인식, 각국의 공조를 통해 해결해 가려는 움직임이 가시화되었다. 우선 해당 중앙아시아 국가들이 환 경문제 해결을 위한 국제 제도와 레짐에 포함됨에 따라 정책 과정은 종종 초국가적 또는 국제적 차원을 띠게 되었고, 국제조약의 법률적 당사자로서 국가의 역할과 중요성이 부각되었다. 그렇 다고 해서 하부국가(subnational) 단위의 시민단체나 초국가(supranational) 단위의 국제기 구와 같은 다양한 비국가 행위자들이 수행하는 역할의 중요성을 무시할 수는 없다. 아랄 해 문 제를 공론화하는데 중심축이 되었던 '아랄 해 살리기 국제펀드' 가 그 좋은 예이다.

그러나 오늘날 아랄 해의 상태는 국제사회와 해당 국가들 간의 공조에도 불구하고 과거의 수 준으로 복구되지 못했으며, 개선, 복구 작업은 국가별로 불균형적, 산발적으로 진행되고 있다.

3) Agreement of the Republic of Kazakhstan, Republic of Kyrgyzstan, Republic of Tajikistan, Turkmenistan, and Republic of Uzbekistan on joint activities in addressing the Aral Sea. http://www.internationalwaterlaw.org/documents/regionaldocs/aral-sea.html

4) 현재 '중앙아시아 수자원 관리 국가 간 위원회' 는 활동의 효율성을 제고하기 위해 '아랄 해 살리기 국제 펀드' 산 하 조직으로 편입되었다. http://www.ec-ifas.org/; http://www.icwc-aral.uz 참조. 
대부분의 국제적 지원이 개방정책을 펼쳐왔던 카자흐스탄에 집중되면서 카자흐스탄 영내 아랄 해는 최근 조금씩 수량이 늘어가는 추세이지만,5) 우즈베키스탄 측 아랄 해는 대부분 고갈된 상 태다. 이러한 생태계 파괴는 주변부에 거주하는 주민들의 건강 상태에도 악영향을 미쳐, 이 지 역은 우즈베키스탄 내에서 평균 사망률이 가장 낮은 지역으로 집계되고 있다. 상황의 심각성을 인식한 우즈베키스탄 정부는 2000년대 말부터 생태환경 정책에 대한 인식 전환을 꾀하였다. 대 표적 사례는 2009년 하원의회 선거에서 15 개의 의석을 '우즈베키스탄 생태운동' 이라는 시민환 경단체에 배분한 것이다. 2008년 설립된 '우즈베키스탄 생태운동' (이하 생태운동) 단체는 우즈 베키스탄 내에서 활동하고 있는 NGO, 비영리기구들의 활동을 조율하는 등 생태환경문제를 총 괄하고, 국제환경기구들과의 협력을 도모하는 역할을 하고 있다.

우즈베키스탄은 중앙아시아 국가들 가운데서도 한국과 활발한 경제, 에너지 협력을 추진하고 있으며 2007년 수립한 원조전략에 따라 우즈베키스탄을 무상원조 사업의 집중원조국으로 지 정, 우즈베키스탄 정부의 발전전략과 부응정도에 따라 맞춤식 원조를 추진 중이다. 최근 우즈베 키스탄 정부는 지속가능한 발전을 위해 생태환경 보호가 선행되어야 함에 서서히 눈을 뜨고 있 다. 그러나 수십 년 동안 진행되어 온 아랄 해 문제와 다양한 환경문제를 우즈베키스탄 한 국가 가 해결하기에는 문제의 규모나 정도가 상당히 심각한 수준이다. 이러한 상황을 극복하기 위해 서는 한국을 비롯한 국제사회의 재정적, 기술적 원조가 반드시 필요하다. 한국 역시 한 때 개발 논리에 따라 국토의 많은 생태환경이 광범위하고 심각하게 파괴되는 모습을 지켜보았고, 이로 인한 직, 간접적 피해를 경험하였다. 다행히도 최근 들어서는 무분별한 개발 대신 지속가능, 상 생하는 성장에 대한 공감대가 크게 형성되어 사회 각 분야와 실생활에 활발히 반영되고 있는 추 세다. 우즈베키스탄이 한국을 정치, 경제 분야에서 자국의 성장 롤모델로 삼고 있는 만큼 생태 환경 분야에서 한국과 경험을 공유하고 문제 해결을 모색한다면 이는 원조를 넘어서서 양 국 간, 나아가 한국과 중앙아시아 국가들 간 유의미한 협력이 될 수 있다.

따라서 이 글은 중앙아시아의 대표적 환경 파괴 사례인 아랄 해 고갈과 오염 실태와 이로 인 해 심각한 피해를 겪고 있는 우즈베키스탄의 생태환경 문제를 소개한 후 국제사회와 우즈베키 스탄 정부가 이를 해결하기 위해 어떠한 노력을 진행해 왔는지 살펴볼 것이다. 결론에서는 향후 한국 정부의 우즈베키스탄을 위한 원조 정책에서 생태환경 분야에 대한 어떠한 지원이 고려되 어야 할지 고민해 보고자 한다.

5) 문화일보, 기후변화 최전선을 가다: 염해 아랄 해, 말라붙은 소금땅으로, 2007, 09, 12일자. (접속일 2009-0823). 


\section{2. 아랄 해의 오염, 고갈 및 주민 보건 실태}

아랄 해와 두 시르다리야, 아무다리야 강은 중앙아시아 국가들의 국경을 공유 혹은 통과하는 국제 수자원이자, 공유 자원이다. 따라서 이들 수자원의 오염, 고갈은 환경적 차원일 뿐만 아니 라 부족한 자원의 공평한 분배 및 효율적 사용이라는 각국의 정치-경제적 문제와도 밀접하게 연관되어 꾸준히 역내 갈등의 주요 원인으로 지목되었다. 과거 소련 통치 하의 중앙아시아는 한 국가에 속한 지방정부였기 때문에 수자원은 중앙의 수자원부(Ministry of Water Resources) 에 의해 통합, 관리되었다. ${ }^{6)}$ 그러나 독립 후 중앙아시아 5 개 국가들은 자국 영토 내 자원에 대 한 주권 및 관할권을 요구하기 시작했고, 중앙아시아 수자원 관리 문제는 각국의 정치-경제적 이해관계가 복잡하게 얽힌 국제적 양상을 갖게 되었다. 최근 우즈베키스탄과 타지키스탄 간 수 자원 분쟁의 사례에서 볼 수 있듯이 중앙아시아 지역에서는 부족한 공유 수자원으로 인한 분쟁 의 기미가 급격하게 발전해가고 있다. 이는 향후 중앙아시아 안보에 부정적 영향을 미칠 주요 요인이기도 하다. 또한 아랄 해의 고갈과 오염 문제는 현재 아랄 해를 공유한 카자흐스탄과 우 즈베키스탄만의 문제로 국한되지 않고, 그 피해 여파가 중앙아시아 전 지역의 극심한 한파와 가 뭄 등 잦은 기상이변 현상으로 이어지고 있다. 단적인 예로 지난 2007년 중앙아시아의 겨울은 유례없이 혹독하였는데, 이로 인해 타지키스탄에서만 동사자가 100여명에 이르렀다. 말라버린 아랄 해가 겨울철 발달하는 시베리아 고기압의 남하를 막아주는 역할을 하지 못했기 때문이다. 또한 여름에 고온 현상이 계속되어 작물 재배에도 큰 타격을 주어 물가 상승의 주요 원인이 되 었다. 즉, 공유 자원에 대한 무차별적 사용과 무책임한 행태가 결국 전체가 치러야할 막대한 비 용으로 돌아온 것이다. 이러한 가운데 수자원과 관련한 중앙아시아 환경문제 해결은 역내 개별 국가의 노력, 국가 간 협력, 연대 역시 절실함을 깨달아 1990년 대 이후부터 생태환경보전을 목 표로 하는 국제, 지역 기구가 태동, 조직적인 활동을 시작했다. 또한 한국과 같은 개별 국가들도 $\mathrm{ODA}$ 나 민간기업의 후원 등을 통하여 인류가 초래한 비극을 함께 극복하고자 움직이고 있다.

그 중에서도 우즈베키스탄은 소비에트 시기 진행된 환경파괴로 오늘날 생태계 피해 및 국민 보건에도 직접적으로 부정적인 영향을 받고 있다. 구 소련권 15 개 국가 중 다섯 번째로 영토가 크지만 국토의 $70 \%$ 가 황무지 및 산지를 이루고 있고 특히 중앙부는 대부분 사막으로 이루어져 있어 수자원의 존재는 국민의 삶과 직결되는 문제이다. 우즈베키스탄 북쪽 국경선과 남쪽 국경 선에는 각각 시르다리야, 아무다리야 강이 흘러 서북부의 아랄 해로 흘러들어간다. 대부분의 도 시들은 이들 두 강을 끼고 형성된 오아시스에 건설되어 있으며, 강 주변에는 인구밀도가 높다.

6) 강봉구, 중앙아시아 나린강/시르다리야강의 국제 수자원 정치, 『KIEP 전략지역심층연구 09-04 중앙아시아

정치 · 사회 · 역사 · 문화」, 181-214. 


\section{그림 1. 아랄 해로 유입되는 아무다리아 강과 관개수로 현황}

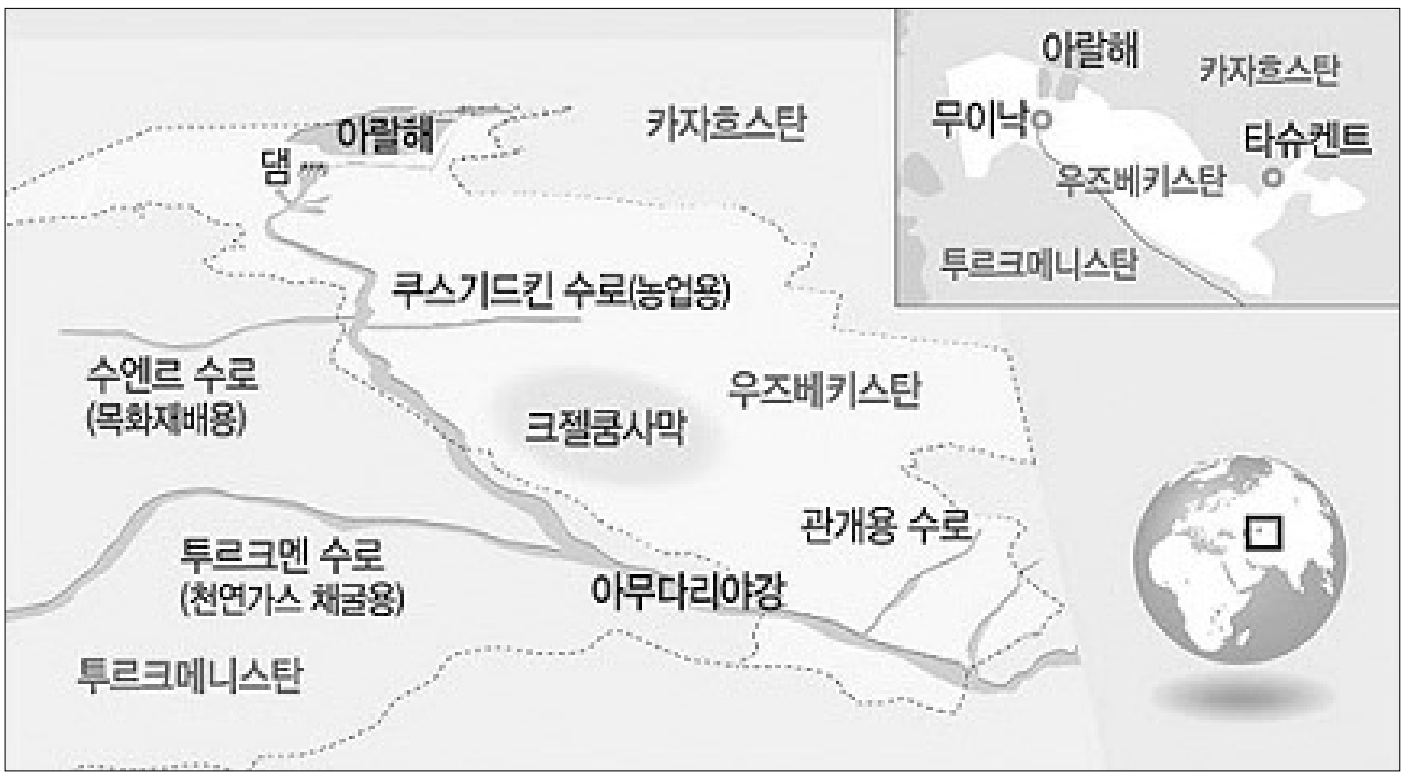

출처: 문화일보, 기후변화 최전선을 가다: 염해 아랄해, 말라붙은 소금땅으로, 2007, 09, 12일자.

아랄 해는 한때 세계에서 네 번째로 큰 내륙호로 해수면 기준, $68,000 \mathrm{~km}^{2}$ 의 면적으로 아일랜 드 국토 면적과 비슷하며 한국 남한 국토 면적의 $2 / 3$ 에 해당하는 크기로 오랫동안 지역주민들 에게 담수어장과 가축을 기를 수 있는 환경을 제공했다. 그러나 1960 년대 이후 소련 정부는 목 화생산 향상을 목적으로 무분별하게 관개수로를 개발하여 두 물주기인 시르다리야와 아무다리 야의 아랄 해 유입을 막았다 (그림 1. 참조). 한 현지 공무원은 “아랄 해가 완전히 마르지 않을 정도로만 물을 흘려보내고 있다” 고 털어놓을 정도다. 7) 그 결과 아랄 해의 수량은 줄어들고 오염 되어 생태계 파괴, 기후 변화, 질병 발생 등 많은 환경문제를 야기하고 있다. 우즈베키스탄 이슬 람 카리모프 대통령은 오늘날 아랄 해의 상황을 “소비에트 시기 중앙 정부의 부분별한, 야만적 인 수자원 사용이 초래한 비극” 이라고 평가했다. ${ }^{8)}$ 특히 아랄 해 면적이 현격히 축소되면서 주민 들은 삶의 터전을 잃게 되었고, 환경적으로는 급격한 기후 변화로 인해 생태계 변화와 각종 환 경질병 발생 등 수많은 문제를 야기하고 있다. 아래 표 1.은 1986년에서 2006년까지 아랄 해의 수위, 수면적, 수량 등을 기록한 것이다. 이 중 지리적으로 우즈베키스탄의 관리 하에 놓여있는 대(大)해의 모든 수치가 기록이 시작된 연도 이래로 현격이 줄어들고 있음을 알 수 있다. 이는 우즈베키스탄 정부가 아랄 해로 흘러들어가는 아무다리야 강의 수량관리에 최근까지도 별다른

7) 상동.

8) Wegerich, K., 2001. Not a simple path: a sustainable future for Central Asia. London: Water Issue Study Group, School of Oriental and African Studies. 
노력을 기울이지 않은 결과이다. 반면, 카자흐스탄 측에 속하는 소(小)해의 경우 미미하긴 하지 만 조금씩 수치가 올라가고 있는데 카자흐스탄 정부가 세계은행의 지원으로 2005년 다이크 코 크 아랄(dyke kok-aral)에 대규모 댐을 건설하여 북쪽에서 아랄 해 소해로 흘러오는 또 다른 강 시르다리아의 물을 모으기 시작했기 때문이다. 카자흐 정부에 따르면 소해의 수량은 댐 건설 이후 약 $40 \%$ 가량 회복되었고, 수상생물 역시 늘고 있다. 9 ) 카자흐의 항구도시 아랄스크에 접했 던 해안선은 $100 \mathrm{~km}$ 나 후퇴했다가 지금은 $25 \mathrm{~km}$ 지점까지 되돌아 왔다. ${ }^{10)}$

\section{〈표 1. 아랄 해 수위, 수면적 및 수량 변화 추이〉}

\begin{tabular}{c|c|c|c|c|c|c}
\hline \multirow{2}{*}{ 연도 } & \multicolumn{3}{|c|}{ 대(大)해 (우즈베키스탄) } & \multicolumn{3}{c}{ 소(小)해 (카자흐스탄) } \\
\cline { 2 - 7 } & $\begin{array}{c}\text { 수위 } \\
(\mathrm{m})\end{array}$ & $\begin{array}{c}\text { 수면적 } \\
\left(1,000 \mathrm{~km}^{2}\right)\end{array}$ & $\begin{array}{c}\text { 수량 } \\
\left(\mathrm{km}^{3}\right)\end{array}$ & $\begin{array}{c}\text { 수위 } \\
(\mathrm{m})\end{array}$ & $\begin{array}{c}\text { 수면적 } \\
\left(1,000 \mathrm{~km}^{2}\right)\end{array}$ & $\begin{array}{c}\text { 수량 } \\
\left(\mathrm{km}^{3}\right)\end{array}$ \\
\hline 1986 & 41,02 & 38,56 & 380,63 & 40,90 & 2,83 & 22,47 \\
\hline 1987 & 40,19 & 37,13 & 343,17 & 40,80 & 2,81 & 22,39 \\
\hline 1988 & 39,67 & 36,18 & 312,65 & 40,50 & 2,75 & 21,84 \\
\hline 1989 & 39,10 & 35,30 & 306,92 & 40,20 & 2,71 & 20,28 \\
\hline 1990 & 38,24 & 33,67 & 280,44 & 40,50 & 2,75 & 21,84 \\
\hline 1991 & 37,66 & 32,02 & 257,16 & 40,40 & 2,73 & 20,92 \\
\hline 1992 & 37,20 & 31,83 & 240,17 & 40,20 & 2,71 & 20,28 \\
\hline 1993 & 36,95 & 31,42 & 231,70 & 39,37 & 2,57 & 18,43 \\
\hline 1994 & 36,90 & 31,31 & 229,87 & 40,10 & 2,69 & 20,01 \\
\hline 1995 & 36,50 & 30,04 & 217,25 & 40,50 & 2,75 & 21,84 \\
\hline 1996 & 35,48 & 28,54 & 195,63 & 40,50 & 2,75 & 21,84 \\
\hline 1997 & 34,80 & 26,91 & 173,44 & 41,20 & 2,91 & 22,67 \\
\hline 1998 & 34,21 & 25,75 & 168,43 & 42,50 & 3,24 & 27,03 \\
\hline 1999 & 33,98 & 24,12 & 147,62 & 36,80 & 2,09 & 12,03 \\
\hline 2000 & 33,50 & 22,93 & 139,53 & 39,80 & 2,62 & 19,26 \\
\hline 2001 & 32,40 & 21,00 & 131,16 & 39,20 & 2,55 & 17,97 \\
\hline 2002 & 32,00 & 18,70 & 110,84 & 39,30 & 2,58 & 18,44 \\
\hline 2003 & 31,50 & 17,30 & 97,23 & 40,00 & 2,65 & 19,77 \\
\hline 2004 & 31,09 & 16,40 & 93,46 & 40,80 & 2,81 & 22,39 \\
\hline 2005 & 30,70 & 15,77 & 89,79 & 41,00 & 2,86 & 22,52 \\
\hline 2006 & 30,40 & 13,47 & 81,35 & 41,80 & 2,99 & 24,01 \\
\hline
\end{tabular}

출처: Project INTAS-0511 REBASOWS.

9) Dam project aims to save Aral Sea, BBC, http://news.bbc.co.uk/2/hi/asia-pacific/6538219.stm (201004-11).

10) 기후변화 최전선을 가다: 염해 아랄해, 말라붙은 소금땅으로, 앞의 글. 
또한 아랄 해는 소련 시절 생화학무기 비밀실험 장소로도 사용, 현재는 카자흐스탄 영토에 속 하는 아랄 해 보즈로즈 데니에 섬은 페스트, 천연두, 탄저병 등 각종 세균으로 가득하여 인근 중 앙아시아 국가들에 전염병, 생태계 파괴 확산이 우려되고 있다. 오염된 아랄 해의 물이 증발하 자 공기 중에는 염분과 기타 오염 물질들이 떠다니게 되어 이 지역 일대 주민들은 장티푸스, 인 후암, 결핵, 각종암 등에 시달린다. ${ }^{11}$

\section{그림 2. 아랄 해 고갈 진행 과정}

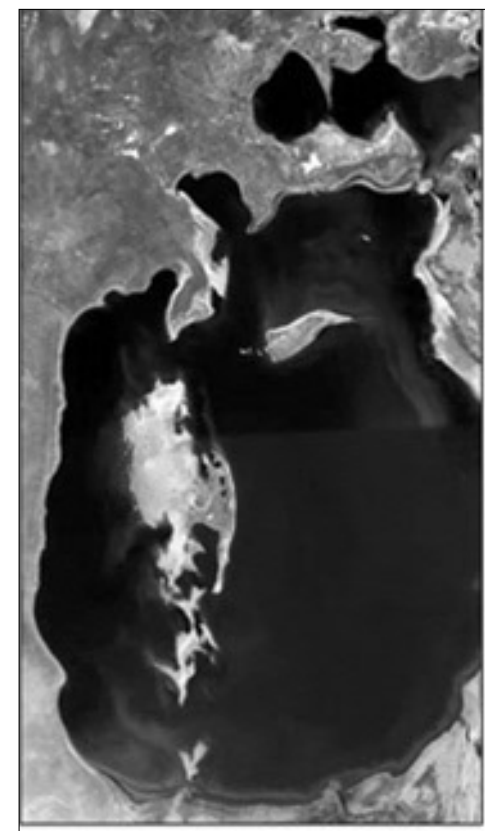

July-September, 1989

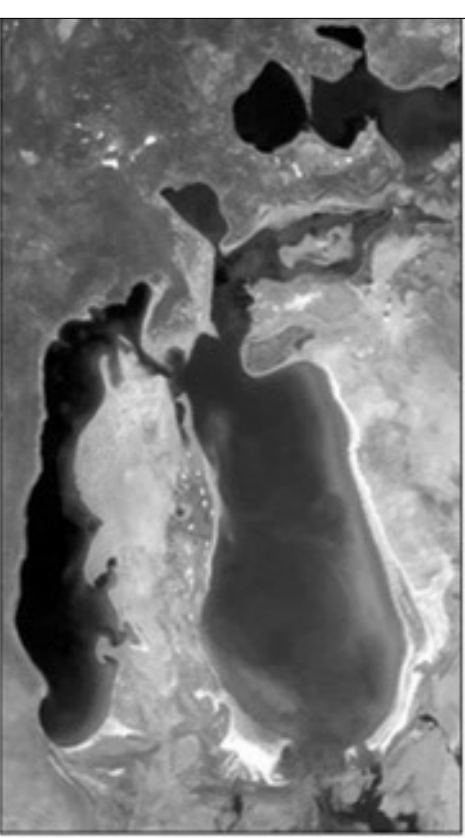

August 12, 2003

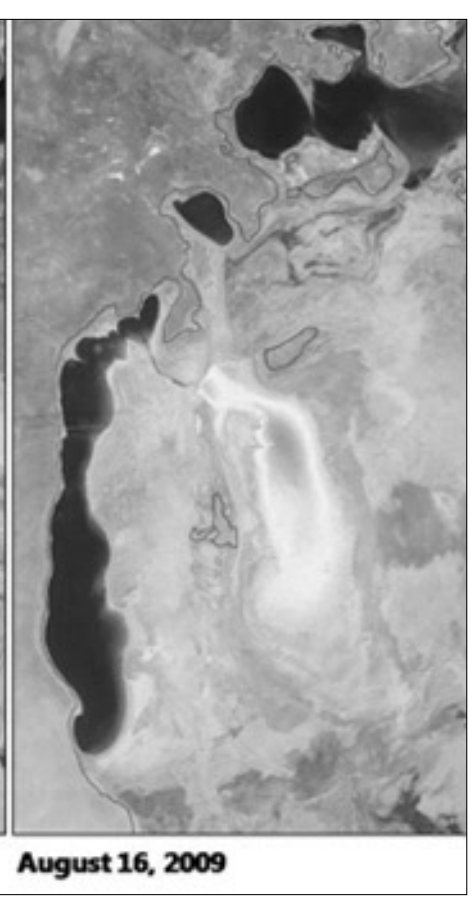

출처: Wikipedia, Aral Sea, http://en.wikipedia.org/wiki/Aral_Sea (검색일 2012-05-15).

오늘날 중앙아시아 지역이 직면한 수자원 관련 문제들은 크게 수자원의 부족과 오염, 안전한 식수에 대한 낮은 접근성, 낮은 수자원 생산성 및 사용 효율성, 국가 법률 제정 개선 미미, 수자 원 관리 부실, 수자원 사용자들의 수자원 서비스에 대한 지불 능력 부족, 제도적 문제, 하수관리 문제, 국제하천 사용의 적절한 규제 부재 등으로 요약된다. 특히 수자원의 오염과 고갈 및 분쟁 문제는 소비에트 통치 시기의 무분별한 수자원 사용과 관리 부재 및 미미로 시작되었다. 소련 붕괴 이후 독립 국가들은 문제의 심각성은 인식했지만 독립 초기 산재한 여러 정치, 경제적 현 안 때문에 본격적인 문제해결을 위한 실질적 노력은 사실상 이루어지지 않았다. 특히 중앙아시

11) 박상남, 현대 중앙아시아, 2010, p. 192-193. 
아 국가들은 독립 이후 피폐한 수자원에 대한 복구와 관리보다는 공유 자원에 대한 소유권, 사 용권 주장에 급급했고, 이로 인해 수자원을 둘러싼 분쟁이 빈번히 발생했다. 공유 자원에 대한 정보 교류도 부족, 향후 수자원 사용량에 대한 예측은 기대하기 어려운 상황이다. 따라서 중앙 아시아 공유 수자원의 보존, 복구, 관리를 위해서는 무엇보다도 역내 국가 간 협력과 개별국가 차원의 문제 해결보다는 범지역적 차원의 해결 방안 모색이 필요하다. 이에 중앙아시아 국가들 은 협력을 위한 법적 수단을 마련하기에 이르렀고, 국제 사회 역시 20 세기 가장 큰 인재로 대표 되는 아랄 해를 복구하고 오염된 주변 생태환경을 개선하기 위한 방안을 촉구하기 시작했다.

\section{3. 역내 기구와 우즈베키스탄 정부의 환경 복구 및 개선 노력}

\section{3-1. 중앙아시아 역내 조직과 국제기구의 활동}

중앙아시아 국가들의 역내 수자원 복구, 보존, 지속가능한 개발에 대한 관심은 독립 직후인 1992년 각국의 합의 하에 구성된 ‘중앙아시아 국가 간 수자원 관리 위원회(ICWC)'로 구체화되 기 시작되었다. ICWC는 중앙아시아 각국 정부의 수자원 장관으로 구성된 조직으로 초기에는 우선적으로 아무다리야와 시르다리야 강 유역의 평화적, 효율적 수자원 관리 및 분배에 국한되 었으나 오늘날에는 중앙아시아 개별국의 수자원 관리, 개발, 역내 수자원에 대한 지속가능하고 친환경적 처리 지속 등 보다 광범위하게 수자원 관리에 직접적으로 관여한다. 12 ) 한편, 19921994 년 사이 고갈해 가는 아랄 해의 비극이 국제사회에 알려지면 형성된 국제 기금에 의해 '아 랄 해 살리기 국제펀드(IFAS)' 와 '아랄 해 국가간 협의회(ICAS)' 가 설립되었다. 초창기 IFAS 의 역할은 사업을 진행하기 위한 자금 모집에 국한되었던 반면, ICAS가 아랄 해 유역 프로그램 (ASBP)를 실행, 실질적으로 아랄 해 복구 사업을 주도했다. 이듬 해인 1993년에는 '지속가능한 개발을 위한 국가 간 위원회(ICSD)' 가 설립, 핵심 임무는 중앙아시아 환경 보호였다. 그러나 늘 어난 국제기구와 역내 조직의 수에도 불구하고 아랄 해 복구 사업과 수자원 관리가 효율적으로 이루어지지 않자, 1997 년 2월 중앙아시아 국가들은 ICAS의 기능을 IFAS로 통합, 재정비에 대 한 합의를 도출하였다. 이후 IFAS는 공유 수자원을 관리하고 아랄 해 파괴 등의 당면 과제 해결 을 핵심 목표로 하는 대표적인 중앙아시아 환경 기구로 활동하고 있다. 이후 ICSD가 담당했던 $\mathrm{ASBP}$ 추진은 IFAS와 ICWC의 협력 하에 실행되고 있다.

12) http://www.icwc-aral.uz/activity.htm (접속일 2012-05-31). 


\section{그림 3. 중앙아시아 국가 간 수자원 관리위원회(ICWC) 집행위원회 조직}

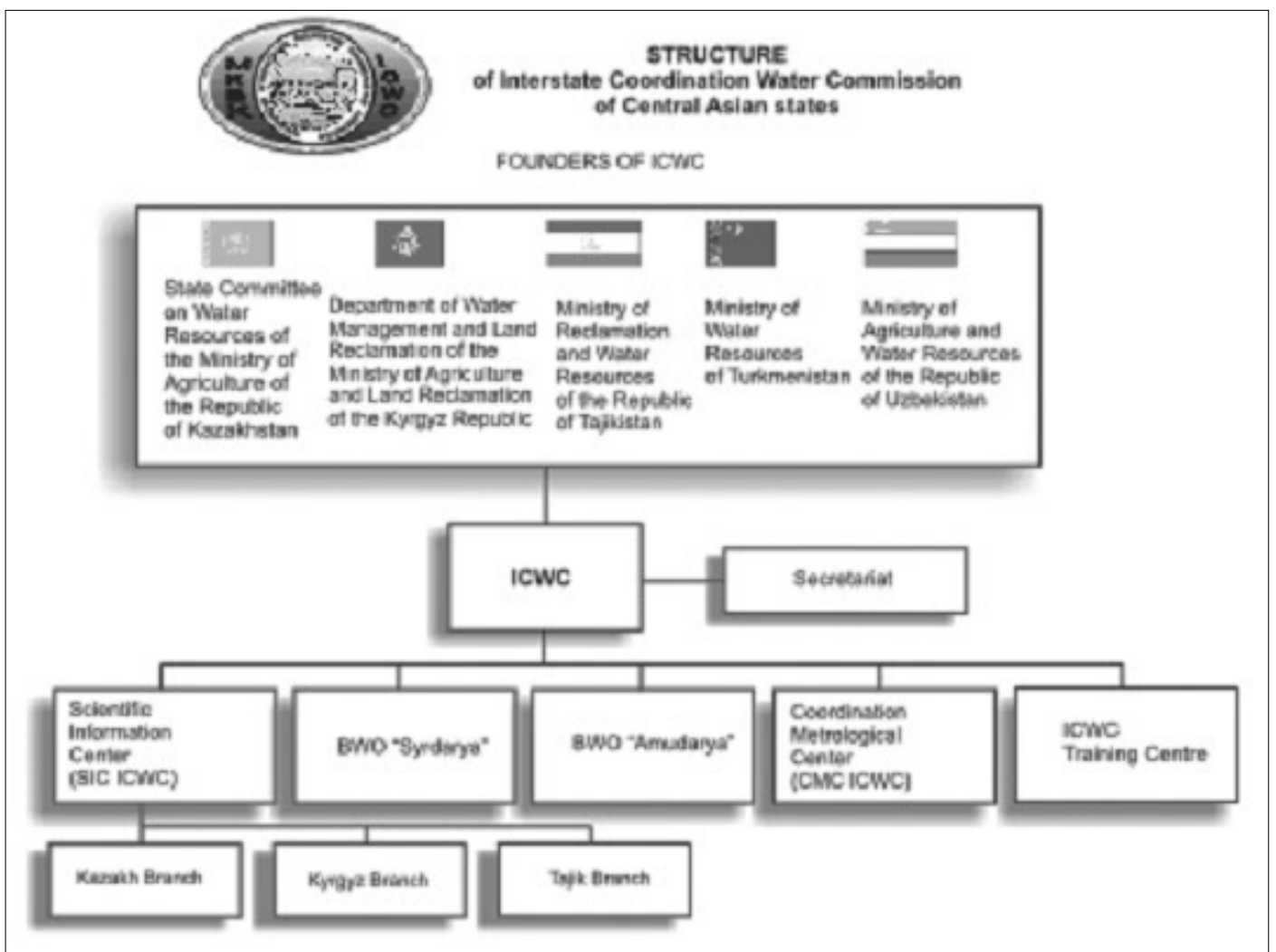

출처: Interstate Commission for Water Coordination, http://www.icwc-aral.uz/activity2.htm (검색일 201205-29).

\section{표 2. ICWC 산하 조직과 주요 업무}

\begin{tabular}{|c|c|}
\hline ICWC 산하 조직 & 주요 업무 \\
\hline $\begin{array}{l}\text { 과학-정보 센터 } \\
\text { (Scientific- } \\
\text { Information } \\
\text { Center ICWC) }\end{array}$ & $\begin{array}{l}\text { - 정보 및 분석 조직으로 수자원 유역의 개발, 생태 환경 개선 및 } \\
\text { 관리에 적합한 방법 개발 } \\
\text { - 중앙아시아 각국의 관련 조직과의 데이터 베이스 공유 작업 }\end{array}$ \\
\hline $\begin{array}{l}\text { 훈련 센터 } \\
\text { (Training Center } \\
\text { ICWC) }\end{array}$ & $\begin{array}{l}\text { - 캐나다 McGill 대학과 Mount Royal College 대학의 지원 하에 } \\
\text { 수자원 관리, 관개사업, 배수, 환경 보호 등에 관한 전문가 육성 } \\
\text { - 각국 전문가와 정책결정가 간 협력과 정보 공유 추진 }\end{array}$ \\
\hline $\begin{array}{l}\text { 합동 계측 센터 } \\
\text { (Coordination } \\
\text { Metrological Center } \\
\text { ICWC) }\end{array}$ & $\begin{array}{l}\text { - 키르기스스탄 가스, 열량 측정에 관한 계측/도량 서비스 } \\
\text { - 아랄 해 유역에 대해 ICWC 계측 서비스 조율 }\end{array}$ \\
\hline
\end{tabular}




\begin{tabular}{|c|c|}
\hline ICWC 산하 조직 & 주요 업무 \\
\hline $\begin{array}{c}\text { 사무국 } \\
\text { (Secretariat ICWC) }\end{array}$ & $\begin{array}{l}\text { - ICWC 산하 조직 내 각종 모임 조율 및 안건 구성 } \\
\text { - BWO 프로젝트 실행 관련 해당국 비용 산출 } \\
\text { - 프로젝트 실행 계획 및 예산 모집 } \\
\text { - 기타 관련 국제기구와의 조율 }\end{array}$ \\
\hline $\begin{array}{l}\text { 아무다리야 강, 시르다 } \\
\text { 리야 강 유역 수자원 } \\
\text { 기구 } \\
\text { (Basin Water } \\
\text { Organization, BWO) }\end{array}$ & $\begin{array}{l}\text { - 유수(water flow) 일정 및 수자원 분배 계획 및 관리 } \\
\text { - 수자원 분배, 방류, 수질 관리 등과 관련하여 ICWC의 결정 내용 } \\
\text { 실행 }\end{array}$ \\
\hline
\end{tabular}

출처: Interstate Commission for Water Coordination, http://www.icwc-aral.uz/bodies.htm (검색일 201205-29).

IFAS의 궁극적 목표는 중앙아시아의 국가적, 지역적 차원에서 현존 수자원을 보다 효과적으 로 사용하기 위해 협력하고, 아랄 해 유역 생태환경 및 사회-경제적 상황을 개선하는 것이다. $\mathrm{EC} \mathrm{IFAS는} \mathrm{IFAS의} \mathrm{상임위원회로} \mathrm{중앙아시아} \mathrm{국가들을} \mathrm{비롯하여} \mathrm{아랄} \mathrm{해} \mathrm{복구에} \mathrm{관심을} \mathrm{가지}$ 는 국제기구 및 원조국들 간의 긴밀한 대화를 촉진하고, 실질적으로 아랄 해 복구 운동을 주관 한다. IFAS의 주요 활동은 '아랄 해 유역 프로그램(Aral Sea Basin Program, ASBP)'으로 1993년 이후 현재까지 ASBP-1, 2가 실행되었고, 최근에는 ASBP-3이 중앙아시아 국가들 모 두가 승인한 가운데 향후 구체적 실행 내용을 검토 중이다. 아랄 해 복구 및 주변 환경 개선 사 업의 시작격인 $\mathrm{ASBP}-1$ 은 1993 년 시작되어 총 4억 달러의 기금을 바탕으로 아랄 해 유역 환경 안정, 아랄 해 파괴 지역 복구, 아랄 해 유역으로 흘러들어가는 국제하천에 대한 관리 강화 및 이 프로그램을 실행, 계획하는 역내 기구의 역량 강화 등을 목적으로 실시되었다. $\mathrm{ASBP}-1$ 의 프로그램에 따라 ICWC는 각 국가 수자원 담당 기관과 ICWC 산하 조직인 '시르다리야, 아무다 리야 강 유역 수자원 기구(Basin Water Organization, BWOs)', '과학-정보 센터 (Scientific-Information Center, SIC ICWC)' 내 데이터들을 상호 연결하는 정보 시스템을 개발하였다. 2002년에 시작된 ASBP-2는 수자원 분쟁해결 메커니즘, 국제하천 수자원에 관한 새로운 구축 등의 내용을 담고 있으며, 2003-2010년 기간 동안 보다 광범위한 차원의 환경, 사 회경제, 및 수자원 관리에 대한 해결 및 실행 방안을 포함한다. ASBP-2의 실행을 위해 20022010년 중앙아시아 각국 정부는 총 20억 달러 활동 기금을 출현했고, 유엔개발계획(UNDP), 세계은행(World Bank), 아시아 개발은행(Asian Development Bank), 미국 국제개발처 (USAID)를 비롯하여 스위스, 일본, 핀란드, 노르웨이 등의 국가들로부터 기금을 충원했다.13) 현재 ASBP-3이 중앙아시아 5 개국의 승인을 받아 향후 실행 계획 중이다.

ASBP-3 의 궁극적 목표는 아랄 해 유역의 환경 조건과 사회-경제적 상황을 개선하는 것이 
다. 이를 위해서는 중앙아시아 수자원의 다목적 사용을 위한 상호 납득할 만한 메커니즘을 개발 하고 통합된 수자원 관리 원칙을 적용하는 것을 중점 실행목표로 선정하고 있다. $\mathrm{ASBP}-3$ 는 총 4 가지 분야에 대한 방향을 설정했는데, 가) 수자원의 통합적 사용, 나) 환경 보호, 다) 사회-경 제적 발전, 라) 제도적, 법률적 수단 개선 등이다. ASBP-3는 EC IFAS의 지휘 하에 ICWC, 수 자원 전문가 집단, 국제기구(세계 은행, EU, USAIDS 등)와 협력하고 있다. 향후 ASBP-3 프 로그램 하에 진행될 프로젝트들은 중앙아시아 각국 정부가 해당 국가의 필요와 조건에 부합하 는 계획안들로 구성되었다. ASBP-3의 핵심 목표의 세부 내용은 표 3과 같다.

\section{표 3. ASBP-3의 핵심 목표 및 세부 내용}

\begin{tabular}{c|l}
\hline ASBP-3 목표 & \multicolumn{1}{c}{ 세부 내용 } \\
\hline 수자원의 통합적 사용 & $\begin{array}{l}\text { 국제하천 관리, 감독체계확립, 모델링 및 데이터베이스화, 유역 계획 } \\
\text { 적 개발, 급수설비 개선 및 안전성 강화, 수문기상학적 서비스 개선, } \\
\text { 지역 협력 강화, 기후변화에 따른 재난에 대비 강화 등 }\end{array}$ \\
\hline 환경 보호 & $\begin{array}{l}\text { 환경 보호 및 개선, 생물 다양성 유지, 시르다리야 및 아무다리야 델 } \\
\text { 타 지역 환경 개선, 산악 환경 개선, 자연과 목초지의 생산성 개선, } \\
\text { 지역별 환경 정보체계 구축 등 }\end{array}$ \\
\hline 사회, 경제적 발전 & $\begin{array}{l}\text { 생활환경 개선, 식수 보급률 향상, 지속가능한 개발, 고용 확대, 수자 } \\
\text { 원 및 권력 공급 체계 개선, 지방의 교육 및 보건의 질 향상 등 }\end{array}$ \\
\hline 제도, 법률적 수단 개선 & $\begin{array}{l}\text { 투명하고 상호 호혜적인 지역 간 대화와 협력 조건 구축, 주요 사안 } \\
\text { 에 대한 정부간, 부처간, 주무 기간 간 자유로운 의견 교환 체계 구 } \\
\text { 축, 수자원 관리에서의 지역 협력을 도모할 제도적, 법률적 메커니즘 } \\
\text { 확립, 수자원 분야 전문가 육성 등 }\end{array}$ \\
\hline
\end{tabular}

출처: JOINT STATEMENT OF THE HEADS OF THE STATES - FOUNDERS OF THE INTERNATIONAL FUND FOR SAVING THE ARAL SEA, http://www.ec-ifas.org/pbam/ (검색일 2012-05-25).

이러한 움직임과 더불어 중앙아시아 지역의 국가들은 최근 밀레니엄 개발 목표(MDG)의 달성 을 목표로 하는 지속가능한 개발 프로그램 하의 통합수자원관리(IWRM) 개념을 확대, 해당 국 가들의 수자원 조항(Water Codes)에 반영되고 있다. 현재 우즈베키스탄의 북동부 지역에 위치 한 페르가나 계곡, 아무다리야와 시르다리야 저지대 등이 새로운 개념이 도입된 통합수자원관

13) JOINT STATEMENT OF THE HEADS OF THE STATES - FOUNDERS OF THE INTERNATIONAL FUND FOR SAVING THE ARAL SEA, http://www.ec-ifas.org/pbam/ (검색일 2012-05-25). 
리 및 수자원 효율 계획에 따라 관리되고 있다.

범지역적 차원의 해결방안 모색 역시 활발히 모색 중에 있다. 우선 협력을 위한 법적 수단 마 련이 WARMAP 프로젝트(1995-2000)를 통해 진행되어 왔다. 1996년 개최된 ICWC 회의에서 는 국제하천의 수자원에 대한 5 개국의 공동 활동의 주요 지침을 다룰 4 개 협약을 준비해야 할 필요성이 대두되어 제도적 준비, 정보 교환, 수자원 이용 규정, 환경 보호와 관련한 결의안이 발 표되었다. 1996년부터 1999년 동안 각국 및 지역 단체를 대표하는 실무 그룹 회의에서는 구체 적인 협의안이 논의, 관련국이 모두 승인하여 실행단계에 접어들 수 있게 되었다. 그 중 하나는 중앙아시아 수자원 정보 교환에 관한 것이다.

3-2. 우즈베키스탄 정부, 시민단체의 노력: '우즈베키스탄 생태운동(Ecological Movement of Uzbekistan)' 단체의 탄생과 활동

‘지속가능한 개발(sustainable development)' 라는 개념은 미래 세대가 자신들의 필요를 충 족할 수 있는 능력을 훼손하지 않으면서 현재의 필요를 충족시키는 경제적, 사회적 발전, 즉, 결 제개발, 사회개발, 환경보호 간의 적절한 균형을 의미한다. ${ }^{14)}$ 우즈베키스탄 정부는 독립 직후부 터 국가 정책상 우선순위에 양적 경제성장과 국내정치안정을 핵심 목표로 설정했던 반면, 지속 가능한 발전 및 환경보전에 대해서는 별다른 노력을 기울이지 않았다. 특히 아랄 해 오염과 고 갈의 직접적인 피해를 입고 있으면서도 관련한 직접적, 적극적 조치는 사실상 이루어지지 않았 다. 그러나 2000년대 후반에 접어들면서 우즈베키스탄은 역내 환경보존 기구의 출현과 국제원 조사회의 지원, 성장에 대한 새로운 인식 태동으로 생태환경에 점차적으로 주목하기 시작했다.

우선 정부차원에서 우즈베키스탄에서 지속가능한 개발과 환경보호에 대한 관심이 국가전략 에 반영된 것은 2005년 '잠정 후생개선전략(Interim Welfare Improvement Strategy: IWIS)' 이 시초이다. I-WIS는 우즈베키스탄의 국가개발계획으로 UN의 새천년개발목표 $(\mathrm{MDGs})$ 로 지정된 8개 목표와 일치하며, 이에 따른 분야별 전략과 정책들이 포함되어 있다. 이 후 I-WIS를 보다 구체화한 '2008-2010 후생개선전략(WIS)' 계획이 2007년 발표되었고, 우 즈베키스탄 정부는 본 계획을 추진하는데 국제원조사회의 지원과 개별 공여국들의 ODA가 필 수적이라는 점을 파악, 분야별 $\mathrm{ODA}$ 유치 계획과 소요예산, 우선순위, 투자 프로젝트 등을 결정

14) 이 개념은 환경과 개발 중 어디에 우선순위를 두어야 하는가 하는 비생산적인 논의를 지양한다. 하지만 이는 대 단히 논쟁적인데, 서로 다른 정치적, 경제적, 사회적, 환경적 관점을 갖는 집단들이 정확한 의미에 대해 견해를 달리하기 때문이다 (존베일리스, 스티브 스미스 편저 2006, 479), 이지은, 중앙아시아 시민사회 발전 가능성 연 구: '우즈베키스탄 생태운동(Ecological Movement of Uzbekistan)' 시민환경단체 성격 분석을 중심으로, 국제 정치논총, 50-5, 2010, 105에서 재인용. 
하였다. 2009년에는 '무상원조 기반의 기술협력 확대를 위한 조치' 를 결의하여 2010-2011년 간 우즈베키스탄이 유치하고자 하는 사업의 우선순위와 프로젝트들이 결정되었다. 이 중 가장 높은 예산 비중을 차지하는 분야는 보건으로 $33.98 \%$ 에 해당하고, 생태계 및 환경 보호, 식수 및 위생 환경 개선 등에 배정된 예산의 비중은 각각 $5.04 \%, 17.77 \%$ 로 전체 투자 예산의 $22.81 \%$ 를 차지했다.

이러한 국제사회의 원조와 우즈베키스탄 정부의 적극적 협력이 실질적으로 실행에 옮겨지는 동시에 우즈베키스탄 국내에서도 지속가능한 개발이 생태환경 보존과 병행되어야 한다는 인식 이 서서히 태동하기 시작했다. 이 중 주목할 만한 일은 아랄 해로 대표되는 우즈베키스탄의 환 경문제 극복과 국민보건에 대한 새로운 접근을 목표로 하는 환경시민단체 '우즈베키스탄 생태 운동(Ecological Movement of Uzbekistan)' 탄생이다. '생태운동' 은 2008년 8월에 창립된 시민단체로 중앙위원회(Central Kengash), 중앙위원회 산하 집행위원회 및 중앙 개정-감독위 원회 등으로 구성된 중앙기구와 지방조직으로 구성되어 있다. ${ }^{15)}$

‘생태운동' 단체의 주요 취지는 시민들과 연대하여 환경과 국민의 건강을 보호하고 정치, 경 제, 사회 개혁을 생태적인 시각에서 추진하자는 데에 있다. 무엇보다도 '생태운동' 은 시민단체 라는 특성을 살려 우즈베키스탄 국민의 적극적인 참여를 유도하고, 낙후된 환경법 개정 및 새로 운 환경법 제정 등을 통해 보다 국민이 쾌적한 환경 속에 살 권리를 보장하며, 나아가 건강 증 진, 다양한 천연자원의 보호와 합리적인 사용 등을 중점 목표로 삼고 있다. 생태운동의 중심 슬 로건은 "건강한 환경-국민의 건강 $(\mathrm{C} \mathrm{oFл} \mathrm{о} \mathrm{м} \mathrm{м} \mathrm{уXи} \mathrm{т} \mathrm{-ин} \mathrm{с} \mathrm{он} \mathrm{с} \mathrm{а} \mathrm{л} \mathrm{о} \mathrm{м} \mathrm{а} \mathrm{т} \mathrm{ли} \mathrm{и}$ и)”이다. ${ }^{16)}$ 현재까지 생태운동이 추진하는 주요 프로그램 내용은 1) 자연보호와 생태환경 향상 에 시민의 참여도 증진; 2) 생태-환경보호에 관련한 기존의 법률 보완 및 신(新) 환경법 제정; 3) 자연환경의 합리적 사용방안 고안; 4) 국민의 삶의 환경 개선, 친 생태적 양육과 교육 체계 발전; 5) 국제적 공조를 통한 생태-환경 보호 추진; 그리고 6) '생태운동' 단체에 참여하는 비 정부, 비영리 조직 간의 활동 총괄 등으로 요약된다. 무엇보다도 '생태운동' 단체가 주목을 받 게 된 계기는 우즈베키스탄 중앙선거위원회가 2009년 12 월에 치러진 하원의원 선거에서부터 총 150 석 중 15 석을 본 단체에 의무적으로 배정하는 결정 때문이었다. 이는 선거라는 경쟁 과정 을 거치지 않고 다른 정당과 나란히 의회에서 입법권을 행사할 수 있음을 의미하며, 따라서 향 후 우즈베키스탄 정치에서 환경에 대해 보다 적극적으로 논의될 수 있을 것으로 기대된다. 환경

15) '생태운동' 단체에 대한 자세한 설명은 '우즈베키스탄 선거관리위원회' 공식 홈페이지에서 참조 (http://elections.uz/eng/political_parties_and_movements/ecological_movement); Э $\mathrm{k}$ о л о ги ч e c k ое движение уз бекистана, www.eco.uz.

16) 이지은, op. cit. 105. 
문제를 의회 내에서 상시적으로 공론화함으로써 보다 적극적인 환경정책을 법제화 할 수 있는 제도적 장치를 마련되었고, 환경문제 전문가들이 의회 내 환경관련 법률을 심의, 입안하는 과정 에 안정적으로 참여할 수 있게 함으로써 국가정책의 우선순위에 환경문제를 설정하는 효과를 가져올 것이라는 의의가 있다.

2008년 출범 후 현재까지 '생태운동' 은 정부 관료들과의 여러 차례 모임에서 생태보존감사 가 제공하는 자료와 국가환경프로그램 집행부 보고서 등에 대한 세미나를 진행했으며, 이러한 모임은 카라칼파키스탄 자치 공화국, 안디잔, 나망간, 타시켄트 등에서도 개최되었다. 또한 하 원의원, 부처 장관 및 위원회장, 지방당국, 기업체 대표, 생태-환경 과학자 등과 정기적 회의를 통해 생태환경 보존에 대한 효과적인 방안 도출에 대해 다양한 의견을 교환하고 있다. 한편 '생 태운동' 은 환경보호에서 시민의 감독을 강화하기 위해 2009년 핫라인을 개설하였다.17) 이 핫 라인은 환경보호, 위생, 전염병 현황 등의 정보를 시민과 관련 단체로부터 수집하여 우즈베키스 탄 전 지역과 공유하기 위한 새로운 방안이다. '생태운동' 은 지방의 사회-경제적 상황과 삶의 환경을 개선하기 위해서 무엇보다도 해당 지역 시민과 지방 당국의 적극적인 참여가 중요하다 는 것에 방점을 두고 있다. 예를 들어 아랄 해 지역권인 '생태운동' 카라칼파키스탄 지부는 현 지 주민들과의 함께 고갈된 아랄 해 지역에 '삭사불(saksavul)' 이라는 묘목 심기 작업을 펼치 는 한편, 정부의 지원을 유치해 낙후된 의료센터를 확충 중이다. 아무다리야 강 부근의 농지 환 경 개선 프로젝트 역시 지역 주민과 학생들의 협력을 통해 실시 중이다. ${ }^{18)}$ 그러나 이러한 복구 노력은 우즈베키스탄 정부 차원에서 보다 적극적으로 진행될 필요가 있음에도 불구하고 현재까 지는 본 환경단체나 해외지원단체의 지원을 받는 수준에 머물러 있다.

'생태운동' 단체는 2009년 의회 선거에서 처음으로 의회에 입성한 후 2010년 3월 회의에서 2010년 주요목표로 1) 향후 우즈베키스탄 환경정책의 기본 방향과 컨셉 구축; 2) 환경특별법 제 정과 기타 환경법 제정, 법률 집행 메커니즘 구성; 3) 국제환경법에 준하는 우즈베키스탄 생태환경법 상정; 그리고 4) 생태-보건 분야의 법률 집행을 위한 다양한 분석활동 등을 설정하였 다.19) 이 중에서도 의회 내 '생태운동' 단체가 2010년도에 가장 주목하고 있는 대상은 1992년 채택된 ‘환경보호법' 과 ‘국가위생감독법' 에 대한 개정과 보완이다. 이러한 환경관련 법률 정비 과정에서 '생태운동' 출신 하원의원들은 국제적 기준을 도입할 필요성을 강조하고 있다. 따라 서 2010년 내로 기존의 환경관련 법규를 총망라하게 될 새로운 ‘환경법' 상정과 채택이 이루어

17) '생태운동' 단체의 활동에 대해서는 홈페이지 (www.eco.uz)의 "Ecological Movement of Uzbekistan marks one year of its activity" 참조.

18) 우즈베키스탄 정부가 최근 추진 중인 생태 프로젝트는 아랄 해가 위치한 카라칼파키스탄 자치공화국에 집중되고 있다 (Two environmental projects launched in Aral Sea area, http://www.gov.uz/en/press/society/3158 (2010-04-12).

19) Uzbekistan Today 2010.3.12 자. 
질 전망이다. 또한 생태운동 소속 의원들은 이들은 올해 중으로 "지속가능한 환경 관리를 통한 경기 부양” 과 “환경감독” 및 “환경 손실” 등과 관련된 새로운 법을 입법화하려고 노력 중이 다. ${ }^{20)}$ 이 외에도 우즈베키스탄 내의 환경 관련 법률 - '토지 코드화' 및 '임야보호', '유해 방 사선 관리', '지하자원 활용' - 등을 생태보존 시각에서 새롭게 수정 및 보완할 예정이다. ${ }^{21)}$

\section{4. 결론: 지속가능한 생태환경 보존과 한국의 향후 협력 방안}

소비에트 시기 무분별한 수자원 사용과 오염으로 비극적 상황에 이른 중앙아시아 환경문제는 '20세기 인간에 의한 최악의 환경재앙' 이라는 수식어를 낳았다. 특히 우즈베키스탄과 카자흐스 탄 국경에 걸쳐 있는 아랄 해는 심각하게 오염되었으며, 90년대 말에는 기존 해수면적의 $90 \%$ 이상을 상실한 것으로 알려졌다. 아랄 해 유역 주민들의 건강 상태가 더 이상 방치할 수 없는 심 각한 상황에 이르러서야 비로소 국제사회와 우즈베키스탄 정부는 이 지역 환경과 국민 보건에 관심을 기울이기 시작, 1990년대부터 국제원조기구와 역내 생태환경보존 기구의 활동이 이루 어지기 시작했다. 우즈베키스탄 국내적으로도 환경보호단체인 '생태운동' 이 발족, 이례적으로 의석의 15 석을 본 단체에 배분하는 등 적극적으로 환경정책을 전개하고 있다. 이로 인해 우즈베 키스탄 정부는 시대에 뒤쳐진 기존의 환경법을 개정하고 국제적 기준에 준하는 강화된 환경법 을 재정 중이다.

그러나 이러한 노력과 의지에도 불구하고 이미 광범위한 범주에 걸쳐 수십 년 동안 진행된 우 즈베키스탄의 환경 문제는 해당 국가만이 해결하기에는 현실적으로 불가능한 상황에 처해있다. 이에 우즈베키스탄 정부는 적극적으로 생태환경 개선을 위한 국제원조기구와 공여국들의 공조 를 요청하고 있으며, 한국의 $\mathrm{ODA}$ 에도 큰 관심을 보이고 있다. 우즈베키스탄은 한국의 중점 협 력대상 국가 중 하나로 1992년 이후부터 2010년까지의 무상원조 규모가 총 2억 8,807만 달러 에 달한다. 이는 CIS 권 국가들을 대상으로 한국이 지원하는 규모 중 1 위를 차지하며, 전 세계 수혜국들 가운데서는 4 위의 규모이다. ${ }^{22)}$ 뿐만 아니라 1996년부터 한국수출입은행의 대외경제 협력기금 $(\mathrm{EDCF})$ 을 통해서도 통신망 현대화, 직업교육시설 개선, 교육정보화, 의료기기공급 등 2009 년까지 총 117.00 백만 달러의 원조가 이루어졌다. 특히 우즈베키스탄이 2007년 전략적

20) 상동.

21) Ekoharakat program, Ecological Movement of Uzbekistan, 2010, 이지은, op. cit, 108쪽.

22) 우즈베키스탄 국별지원전략 및 지원사업 종합평가, (2010.12), 한국국제협력단(KOICA), 3쪽. 
원조 제공이 필요한 국가로 선정된 이후부터는 기존에 다소 산발적으로 추진된 협력 사업이 보 다 체계화, 구체화되고 있다. 우즈베키스탄 현지에서도 한국의 KOICA나 대외경제협력기금 및 다양한 분야를 대상으로 한 민간단체의 지원 사업들은 큰 호응을 얻고 있으며 결과에 대한 만족 도도 높게 나타나고 있다.

원조 규모의 증가와 함께 우즈베키스탄의 환경문제와 수자원 관리에 대한 국제사회와 한국의 지원도 최근 들어 증가추세이다. 2010년도 UN 반기문 사무총장은 우즈베키스탄 아랄 해 유역 을 방문하여 직접 실태를 확인하였고 국제기구들의 가능한 자원을 동원하여 아랄 해 복구에 힘 쓰겠다고 밝힌 바 있다. 또한 한국의 수출입은행 $\mathrm{EDCF}$ 사업은 앞으로 환경보호 및 지속가능한 환경자원 활용을 통해 우즈베키스탄 국민들의 삶의 질을 한 단계 높이는 쪽으로 초점을 맞출 계 획이다. 차기 프로젝트는 상하수도 시설 개선으로 물이 부족한 우즈베키스탄의 식수 시스템을 효율적으로 개선하기 위한 지원(5160만 달러)을 계획하고 있다. 이번 지원으로 노후한 기존의 상하수도관 시설을 교체하고 새로운 시설을 확충, 주민들의 물 부족을 해소하고 쾌적성을 높일 예정이다. 또한 한국의 민간기업들 가운데는 대성그룹이 신재생에너지 기술을 활용해 우즈베키 스탄 아랄 해 지역 생태계와 생활환경을 복구하는 프로젝트에 착수하기 위한 양해각서를 체결 했다. ${ }^{23)}$ 2011년 대성그룹은 우즈베키스탄 정부 산하기관인 '아랄 해 유전자 보호를 위한 자선 기금(Charity Social Fund for Aral Gene Pool Protection)' 과 아랄 해 복원 프로젝트에 협 력, 아랄 해 인근에서 농업과 어업에 종사하다 수량고갈로 생존의 극한까지 몰린 주민들을 위해 신재생에너지 기술을 활용해 지하수를 개발하고, 마을 주민들에게 식수와 생활, 농업용수를 공 급할 계획을 가지고 있다.

이러한 움직임에 따라 한국의 우즈베키스탄 원조 역시 새로운 변화를 적극적으로 반영하여 추 진되어야 할 것이다. 그동안 한국의 원조는 대부분 직업, 교육 개발이나 사회간접자본(SOC)에 집중되어 온 반면, 환경복구나 생태보존 등에는 큰 비중을 두지 않은 것이 사실이다. 이는 한국 의 우즈베키스탄 지원 사업이 초기에는 연도별 무상, 기술협력사업에 주력하였고, 2000년대 후 반부터는 중앙아시아의 에너지 자원 확보라는 '자원외교' 를 염두에 두고 추진되었기 때문이다. 또한 원조가 수혜국 정부의 요청과 승인에 근거하여 당시의 필요 분야에 따라 이루어져야 했기 때문에 한국의 $\mathrm{ODA}$ 지원도 특정 분야에 한정될 수밖에 없었다. 그러나 한국의 ODA 정책이 2007년 원조전략 구축에 따라 보다 전문화된 방향으로 나아감에 따라 5년이 지난 현재 시점에 서 수혜국 필요분야에 대한 변화를 면밀히 분석할 필요가 있다. 이러한 검토와 분석이 향후 한 국의 우즈베키스탄 원조 정책에 적극적으로 반영된다면 더욱 시의성 있는 원조가 이루어질 수

23) 대성그룹, 신재생에너지로 아랄해 생태계 복구 나선다, (2011.8.24일자),

http://economy.donga.com/total/3/01/20110824/39765041/1 (2012-05-16). 
있을 것이다. 앞서 언급한 바와 같이 2008년 우즈베키스탄 정부가 국가발전계획인 WIS를 통해 생태계 및 환경 보호, 식수 및 위생 환경 개선 의지를 밝히고 이에 대한 국제사회의 원조를 요청 한 바, 한국의 향후 ODA 정책 역시 수혜국 맞춤 지원전략에 따라 조정, 원조의 효율성을 높일 필요가 있다. 이를테면 현재 우즈베키스탄 아랄 해 인근 수르길 가스전 개발 및 가스화학플랜트 건설, 운영 사업을 맡게 된 만큼 이 지역의 생태환경 복구나 주민 보건환경에 대한 지원도 병행 하여 추진한다면 한국 역시 중장기적인 차원에서 우즈베키스탄과 더욱 우호적인 협력관계를 구 축할 수 있을 것이다. 이 밖에도 환경보존과 개발, 생태계 복구 등에 대한 직접적인 지원과 함께 역내 기구에서 추진하는 프로그램에 대한 지원, 참여 또는 우즈베키스탄 '생태환경' 과 같은 입 법권을 가진 환경단체의 활동을 지원하거나 이와 연대하여 원조 정책을 추진하는 것도 효과적 인 지원 방안으로 검토될 수 있다. 


\section{참고문헌}

\section{1. 국내문헌}

강봉구 (2009), “중앙아시아 나린강/시르다리야강의 국제 수자원 정치”, $\mathrm{KIEP}$ 전략지역심 층연구 09-04 중앙아시아 정치·사회·역사·문화』, 181-214.

김대성 (2009), 『중앙아시아학 입문』, 한국외국어대학교 출판부.

박상남 (2010), 『현대 중앙아시아』, 한신대학교 출판부.

박창규 (2006), "아랄해역의 환경문제와 수자원 관리의 변화와 과제”, 『중앙아시아 연구」. 제 11호, 253-271.

이지은 (2010), "중앙아시아 시민사회 발전 가능성 연구: ‘우즈베키스탄 생태운동(Ecological Movement of Uzbekistan)' 시민환경단체 성격 분석을 중심으로, 50-5, 국제정치논총, 93-123. 존 베일리스, 스티브 스미스 편저 (2006), 『세계 정치론』, 을유문화사.

Daniel Stevens (2007), "Political society and civil society in Uzbekistan - never the twain shall meet?, Central Asian Survey, vol. 26(1), 49-64.

Garrett Hardin (1968), "The Tragedy of the Commons", SCIENCE, vol. 162, 1243-1248.

Joseph MacKay (2009), "Running dry: international law and the management of Aral Sea depletion”, Central Asian Survey, vol. 28(1), 1727.

우즈베키스탄 국별지원전략 및 지원사업 종합평가, 한국국제협력단(KOICA), 2010.

\section{2. 인터넷 자료}

기후변화 최전선을 가다: 염해 아랄 해, 말라붙은 소금땅으로, 문화일보, $2007,09,12$ 일자. (접속일 2009-08-23).

대성그룹, 신재생에너지로 아랄해 생태계 복구 나선다, (2011.8.24일자), http://economy.donga.com/total/3/01/20110824/39765041/1 (2012-05-16).

Action Report For International Fund For Saving the Aral Sea 2002-2008. http://waterwiki.net/images/2/26/IFAS_final_report.pdf (2010-04-22). Aral sea loss and cotton, http://www1.american.edu/ted/aral.htm (2010-04-09). 
Address by President Islam Karimov at the joint session of Legislative Chamber and the Senate of Oliy Majlis of the Republic of Uzbekistan, http://www.uzbekistan.gr/view_post.php?id=85 (2010-04-10).

Dam project aims to save Aral Sea, BBC, http://news.bbc.co.uk/2/hi/asia-pacific/6538219.stm (2010-04-11).

JOINT STATEMENT OF THE HEADS OF THE STATES FOUNDERS OF THE INTERNATIONAL FUND FOR SAVING THE ARAL SEA, http://www.ec-ifas.org/pbam/ (2012-05-25).

Miraculous Catch in Kazakhstan's Northern Aral Sea, The World Bank, June 2006. http://go. worldbank. org/J4UFHM4SQ1 (2008-05-17).

North Aral Sea Recovery, The Earth Observatory, NASA, 2007.

http://earthobservatory. nasa.gov/Newsroom/NewImages/images. php3?img_id=17634 (2008-05-17).

Priorities of the Ecology Movement, Uzbekistan Today, 2010.3.12, http://www.ut.uz/eng/today/priorities_of_the_ecology_movement.mgr (2010-04-05).

Uzbekistan's Ecological Movement Demonstrates Against Tajik Aluminum Company, CACI Analyst, 2010.4.14, http://www. cacianalyst.org/q=node/5308 (2010-05-01).

O’zbekiston Ekologik Harakati Faoliyati Bo' yicha Ma' lumotnoma Sharifxo' jaev, Murod. O’ zbekistonda ochiq fuqarolik jamiyatining shakllanishi. Toshkent, 2003.

Sog' lom fikr ustun bo' lsin, Ekoharakat (2010.9.17).

http://www.jamiyatgzt.uz/uzb/ekologik_harakat/soglom_fikr_ustun_bolsin.mgr (검색일 2012. 5. 7).

\section{3. 웹사이트}

Uzbekistan Today. http://www,ut.uz.

Ferghana.ru. http://www.ferghana.ru.

CAWATERinfo, http://www.cawater-info.net/index_e.htm.

The International Fund for Saving the Aral Sea (IFAS), http://www.ec-ifas.org.

Ecologic Movement of Uzbekistan, http://www.ecoforum.uz. 
EcoForum, http://www.ecoforum.uz.

Central Election Committee of Uzbekistan.

http://elections.uz/uzb/index/msk_haqida/

Interstate Commission for Water Coordination, http://www.icwc-aral.uz. 